\title{
THE ROLE OF ALTRUISM AND EMPATHY IN ANTICIPATING THE ATTITUDE TOWARD ORGAN DONATION AMONG NURSES IN INTENSIVE CARE UNITS OF QAZVIN: A CROSS-SECTIONAL STUDY
}

\author{
Yekefallah Leili ${ }^{1}$, Dehghankar Leila², Taherkhani Mahnaz ${ }^{3}$, Ranjbaran Mehdi ${ }^{4}$ \\ ' PhD of Nursing, Social Determinants of Health Research Center, Faculty of Nursing and Midwifery, \\ Qazvin University of Medical Sciences, Qazvin, Iran \\ ${ }^{2}$ Department of Nursing, Social Determinants of Health Research Center, Faculty of Nursing \\ and Midwifery, Qazvin University of Medical Sciences, Qazvin, Iran \\ ${ }^{3}$ Student of MSc Nursing, Faculty of Nursing and Midwifery, Qazvin University of Medical Sciences, \\ Qazvin, Iran \\ ${ }^{4}$ School of Public Health, Qazvin University of Medical Sciences, Department of Epidemiology \\ and Biostatistics, School of Public Health, Tehran University of Medical Sciences, Tehran, Iran
}

\begin{abstract}
Aim: Nurses, especially nurses in ICUs play an important role in organ donation; their performance in relation to their role is more affected by their attitude in this regard, identification of effective factors on the positive attitude of nurses towards organ donation is essential. This study was conducted aimed to determine the empathy and altruism with the nurses' attitudes in intensive care unit towards organ donation and brain death. Methods. In this cross-sectional study, which was conducted in 2019, 222 nurses from intensive care unit were selected by stratified random sampling. For collecting data the questionnaires of altruism, empathy and attitude toward organ donation were completed by nurses. Data was analyzed using pearson correlation, multiple linear regression. Results. There was a significant correlation between altruism $(\mathrm{p}<0.001, \mathrm{r}=0.24)$ and its components (anonymous prosocial behaviors $(\mathrm{r}=0.33, \mathrm{p}<0.001)$, emotional prosocial behaviors $(\mathrm{r}=0.14, \mathrm{p}=0.03)$, dire prosocial behaviors $(\mathrm{r}=$ $0.14, p=0.03)$ and compliant prosocial behaviors $(r=0.21$ and $p=0.001))$ with attitudes and also between empathy $(\mathrm{r}=0.04, \mathrm{r}=0.13)$, perspective taking component $(\mathrm{p}=0.02, \mathrm{r}=0.152)$ and imaginary empathy $(\mathrm{r}=0.14$, $\mathrm{p}=0.03$ ) with nurses' attitudes. The components of anonymous prosocial behaviors in altruism $(\mathrm{p}<0.0001)$, gender $(\mathrm{p}=0.007)$ and having organ donation card $(\mathrm{p}=0.012)$ are positive predictors of nurses' attitudes towards organ donation. Conclusion. The results showed that altruism and having organ donation card were two of the most important factors in the tendency of nurses to organ donation. Therefore, the implementation of educational programs regarding changing nurse's attitude in order to increase the sense of altruism and empathy about organ donation is necessary. By strengthening the sense of altruism and empathy in the family of brain death patients, they can be helped to decide on donate their patient's organ with more certainty.
\end{abstract}

Key words: Altruism, Empathy, Attitude, Organ Donation, Nurses.

Corresponding Author: Mahnaz Taherkhani, Student of MSc Nursing, Faculty of Nursing and Midwifery, Qazvin University of Medical Sciences, Qazvin, Iran.

Tel.0982833338034.Fax.0982833338034.E-mail: mahnaztaherkhani55@gmail.com 


\title{
РОАЬ ААЬТРУИЗМА И ЭМПАТИИ В ОТНОШЕНИИ K АОНОРСТВУ ОРГАНОВ У МЕАСЕСТЕР В ОТАЕАЕНИЯХ ИНТЕНСИВНОЙ ТЕРАПИИ В КАЗВИНЕ: ПЕРЕКРЕСТНОЕ ИССАЕАОВАНИЕ
}

\author{
Yekefallah Leili', Dehghankar Leila ${ }^{2}$, Taherkhani Mahnaz ${ }^{3}$, Ranjbaran Mehdi ${ }^{4}$ \\ 'PhD of Nursing, Social Determinants of Health Research Center, Faculty of Nursing and Midwifery, \\ Qazvin University of Medical Sciences, Qazvin, Iran \\ ${ }^{2}$ Department of Nursing, Social Determinants of Health Research Center, Faculty of Nursing \\ and Midwifery, Qazvin University of Medical Sciences, Qazvin, Iran \\ ${ }^{3}$ Student of MSc Nursing, Faculty of Nursing and Midwifery, Qazvin University of Medical Sciences, \\ Qazvin, Iran \\ ${ }^{4}$ School of Public Health, Qazvin University of Medical Sciences, Department of Epidemiology \\ and Biostatistics, School of Public Health, Tehran University of Medical Sciences, Tehran, Iran
}

\begin{abstract}
Цель. Медицинские сотрудники среднего звена, особенно медсестры в отделениях реанимации и интенсивной терапии, играют важную роль в донорстве органов. На их работу влияет множество различных факторов, и поэтому важно определить, какие из них являются эффективными для формирования положительного отношения медсестер к донорству органов. Это исследование было проведено с целью определения уровня эмпатии и альтруизма к донорству органов и смерти мозга у медсестер отделений реанимации интенсивной терапии. Материалы и методы. В этом перекрестном исследовании, которое проводилось в 2019 году, было отобрано 222 медсестры из отделений реанимации и интенсивной терапии с помощью стратифицированной случайной выборки. Для сбора данных медсестры заполняли анкеты, по которым в дальнейшем были оценены их уровни альтруизма, эмпатии, а также отношение к донорству органов. Данные были проанализированы с использованием корреляции Пирсона, множественной линейной регрессии. Результаты. Наблюдалась значительная корреляция между альтруизмом $(\mathrm{p}<0,001, \mathrm{r}=0,24)$ и его компонентами (анонимное просоциальное поведение $(\mathrm{r}=0,33, \mathrm{p}<0,001)$, эмоциональное просоциальное поведение $(\mathrm{r}=0,14, \mathrm{p}=0,03)$, отрицательное просоциальное поведение $(\mathrm{r}=0,14, \mathrm{p}=0,03)$, просоциальное поведение $(\mathrm{r}=0,21, \mathrm{p}=0,001)$ с отношением к донорству органов, а также между эмпатией $(\mathrm{r}=0,04, \mathrm{r}=$ $0,13)$, компонентом, учитывающим перспективы $(\mathrm{p}=0,02, \mathrm{r}=0,152)$ и воображаемым сочувствием $(\mathrm{r}=$ $0,14, \mathrm{p}=0,03)$ с отношением медсестер к донорству органов. Компоненты анонимного просоциального поведения при альтруизме $(\mathrm{p}<0,0001)$, пол $(\mathrm{p}=0,007)$ и наличие карты донорства органов $(\mathrm{p}=0,012)$ являются положительными предикторами отношения медсестер к донорству органов. Выводы. Результаты показали, что альтруизм и наличие карты донорства органов были двумя наиболее важными факторами в положительном отношении медсестер к донорству органов. Следовательно, необходима реализация образовательных программ, касающихся изменения отношения медсестер к посмертному донорству органов. Укрепляя чувство альтруизма и эмпатии в семье пациента со смертью мозга, можно помочь с большей уверенностью принять решение о пожертвовании органа своего близкого человека.
\end{abstract}

Ключевые слова: альтруизм, эмпатия, отночение, донорство органов, медсестры.

\section{INTRODUCTION}

The issue of the organ transplantation has long been propounded in social and scientific circles. It is considered as the best treatment for the terminal and irreversible organ failures and it saves lives in patients with such failures and improves their quality of life [1]. Transplantation is a therapeutic method that is used when all other therapeutic methods fail. It is one of the complex methods that require an expert team from the very beginning of supplying the organ [2]. One of the potential and considerable sources of supplying organs for transplantation is the brain death patients [3]. Many years ago, after the adoption of the law on organ donation, the concept of the organ transplantation was established in Iran and many efforts have been made to promote this humanitarian action with ethical considerations. However, the rate of organ donation is still very low compared to the number of brain deaths [4]. According to the report of the Iranian Association of Organ Donation, every ten minutes one person is added to the waiting list and every two hours a patient who needs the organ transplantation loses his or her life. It is while a person dies with a brain death every 70 minutes. Due to a shortage of donated organs, the number of organ transplantations is much lower in Iran than Europe and the United States so that thousands of people die every year due to lack of access to the required organs [5]. In our country, the rate of organ donation per 
one million people is 2.3 transplantations while Spain with 35 transplantations per million populations has the best situation in this regard, and in other European and American countries, this number ranges from 10 to 25 transplantations per one million people [6].

The difference between the number of people waiting for organ transplantation and the number of people donating their organs is annually increasing worldwide, and this continuing condition makes it necessary to understand how psychological factors can increase people's willingness to donate their organs [7]. According to studies, factors such as prior knowledge of the deceased's wishes (such as signing a donor card), the presence of relatives at the time of the donor's injury, clear and accurate information about the cause and diagnosis of brain death and the benefits of organ donation, the understanding of tests confirming brain death, encouraging organ donation, willingness to help others, ensuring high quality care and respect for the donor's body, good and proper relationship with families and meeting their needs (including mental and social needs), and altruism and empathy are the main reasons for the agreement of the families of brain dead patients with organ donation [8].

Altruism which is one of the prosocial behaviors is often recognized as one of the fundamental principles of organ transplantation [9]. According to the research, four types of prosocial behaviors have been introduced so far, including altruistic prosocial behaviors that are defined as voluntary helping motivated primarily by concern for the needs and welfare of others and often induced by sympathy responding and internalized norms and principles consistent with helping others [10]. Buttson believes that altruism is to understand the others' suffering and to experience the sympathetic concern for others [11]. compliant prosocial behaviors that are defined as helping others in response to their verbal or non-verbal requests [12]; emotional prosocial behaviors that are defined as helping others under emotionally evocative circumstances and are divided into two subsets of emotional prosocial behaviors and dire prosocial behaviors. Highly emotionally evocative situations lead to overarousal and personal distress for some people, while the response may be sympathy for others [13]; and public prosocial behaviors that are divided into the two subsets of anonymous behavior as helping without knowledge of who is helped and public prosocial behavior as a tendency to perform prosocial acts in front of others [10]. In various studies, including Milaniak (2018), Khani (2017), Newton (2011), and Hill (2016), it has been recognized that altruism is one of the main reasons for the willingness to donate organs $[7,14,15,16]$.

Empathy is also considered as an important predictor of various helping behaviors [17]. In studies conducted on empathy, the main focus has been on its definition, cognition, and sometimes on emotion. According to Davis, empathy is not defined as a single dimensional structure (cognitive or emotional), but it consists of a set of constructs structures. Davis considers four components for empathy, including perspective taking as the ability to consider others' perspectives, fantasy as the tendency to imaginary replace oneself into feelings and actions of fictitious characters in books and movies, empathic concern as other-oriented feelings of sympathy and concern for others in distress, and personal distress as self-oriented feelings of personal distress, discomfort, and anxiety in interpersonal conditions [18]. In general, empathy involves sympathy and a willingness to comfort others' suffering [11]. Therefore, empathy can also be linked to the willingness of people to donate an organ [17]. However, the role of empathy in decision making on the organ donation has rarely been considered and only a few studies have been conducted in this field [7]. Cohen et al. (2012) concluded in their study that there was a positive and significant relationship between empathy and the willingness to donate an organ among the students [17]. In the study by Milaniak (2018), a significant correlation was recognized between altruism, empathy and decision making about organ donation among nursing and paramedical students [7], while no significant relationship was found between the consent for the organ donation and the level of empathy in the study conducted by Wilczek et al. (2014) [19].

The organ donation process begins by determining which patients can be suitable for the donation of an organ. For organ donation, brain death should be confirmed by the brain death confirmation association, and the shorter the time interval between the admission of the patient and the confirmation of brain death, the more the number of organs, especially the lungs, which can be transplanted [20]. According to the mortality pattern, the need for living donors can be reduced in developing countries, such as Iran and other Mediterranean countries, by improving the quality of health care, identifying effectively brain death, and obtaining the consent using appropriate strategies [21].

As the primary caregiver of the patient, a nurse in intensive care units may be the first person who diagnoses the patient's lack of response as a sign of brain death [22]. Nurses, especially nurses in the emergency and intensive care units, play an important role in the organ donation process, ranging from identifying and evaluating potential donors to supporting their families to participate in organ donation. Providing information accurately, transparently, sensitively and in a professional manner information to the families of these patients, the nurses make them ready to understand why their dear ones are in such critical conditions and help them to accept easily their deaths, and thus consider the option of donating organs [23]. The performance of nurses in relation to their role in the organ donation process is more affected by their attitudes toward the organ donation, and those who have a more positive attitude to it have better performance in this regard [24]. 
Different studies conducted in Iran and other countries to assess the knowledge and attitude and performance of nurses in relation to the brain death and organ donation process indicate that nurses have poor knowledge, attitude, and performance toward the organ donation process $[6,24,25]$. Given that we live today in a society where thousands of patients in need of organs are waiting for transplantation with a painful life while we face every day with many brain dead patients whose organs can improve the life quality of patients who need the organs, as well as considering the role of nurses in the organ donation process, it is very important to recognize the factors affecting the attitude of nurses toward organ donation. Therefore, to determine the relationship between empathy and altruism and the attitudes of nurses in intensive care units toward organ donation and brain death, the present study has been conducted to understand which steps should be taken to strengthen the status of this important current priority in the medical community.

\section{METHOD}

The present research has been a cross-sectional descriptive-analytic study. The statistical population of this study included all nurses who were working in ICU, dialysis and emergency units of educational and health centers in Qazvin at the time of the research. Using the equation $n=\left(Z^{2} \times S^{2}\right) / d^{2}$, the sample size was calculated to be 208 people considering the confidence level of $95 \%$, the $\mathrm{d}=0.8$, and the maximum standard deviation (SD) of nurses' empathy score of 5.88, obtained in the study by Milaniak et al. (2018) [7]. Taking the probability of sample loss into account, the sample size was considered to be 229 people to enhance the validity of the results of the study.

The sampling was performed using a stratified random method so that the units of each hospital were considered as one stratum and the samples were taken using a simple random method from each stratum which included various intensive care units based on the ratio of nurses in those units to the total population by drawing lots from the list of nurses in the random number table. The exclusion criteria in the present study were having the work experience less than one year in intensive care units, lack of interest in participating in research, having a history of donating an organ or transplantation and or the need for an organ donation in family and relatives, the withdrawal from participating in the study, the completion of years of service, and the change of service place before the completion of the research.

\section{THE TOOLS USED TO COLLECT DATA IN THIS STUDY INCLUDED:}

- Demographic and occupational information questionnaire with 8 questions to collect data such as age, gender, marital status, religion, type of employment, degree of education, organizational position, and work experience of the participant in intensive care units.

- Carlo's prosocial tendencies measure (PTM-R) with 25 questions, including 5 subscales of anonymous prosocial behaviors (7 items), altruistic and public prosocial behaviors ( 8 items), emotional prosocial behaviors (3 items), dire prosocial behaviors (4 items), and compliant prosocial behaviors (3 items). The questionnaire was scored by a 5-point Likert scale ranging from «doesn't describe me at all» to» describes me fully» with points $1,2,3,4$, and 5 respectively. The $5^{\text {th }}$ subscale was scored in reverse order. In this test, score 5 indicates the highest degree of altruistic behavior and the highest score is equal to 125 . The validity and reliability of this tool have been analyzed separately for each subscale by Carlo et al. (2003) and it has been recognized that they are desirable [26]. Additionally, its validity and reliability have been studied in Iran by Kajbaf et al. (2010) and using a test-retest method, the reliability coefficient of this tool has been calculated by the Cronbach's alpha of 0.86 to be 0.863 [27].

Davis Empathy Questionnaire:

- Empathy questionnaire with 28 questions, which has been developed by Davis in 1983, to measure empathy. It measures the four subscales of personal distress, empathic concern, perspective taking, and fantasy. Each subscale in this test includes 7 sentences that are scored based on a 5-point Likert scale (ranging from $0=$ strongly disagree to $4=$ strongly agree) and the questions $3,4,7,12,13,14,15,18$, and 19 are scored in reverse. The minimum and maximum score for each subscale can be 0 and 28, respectively. A higher score indicates more empathy. In the study by Davis, the test-retest reliability of the tool has been equal to $0.61-0.79$ for men and $0.62-0.81$ for women, while the internal reliability has been equal to $0.71-0.77$. and its validity is reported to be desirable [28]. In Iran, the study conducted by Khodabakhsh et al. (2012) has calculated the test-retest reliability of the tool to be 0.71 [29]. In the study conducted by Alah Gholilo et al., the Cronbach's alpha coefficient and the reliability coefficient of this tool has been reported as 0.77 and 0.76 , respectively [30].

- Attitudes toward organ donation questionnaire with 13 questions, which has been developed by Chakradhar et al. The scores given to each item in this tool range from $1=$ strongly disagree to $5=$ strongly agree and the total score may vary from 13 to 65 . Obtaining a higher score indicates a more positive attitude toward organ donation. The validity of this questionnaire has been determined by the content validity in a study by Purbahram et al. (2017). Its reliability has also been calculated by Cronbach's alpha coefficient in the same study to be $76.3 \%$, which is considered as acceptable reliability [31]. 
The present study has been conducted as a student thesis. After obtaining a license from the Ethics Committee of the Qazvin University of Medical Sciences (IR.QUMS.REC.1397.179), obtaining a letter of introduction from the university's research deputy, providing the necessary explanations regarding the purpose of the research, and obtaining the written consent of the participants, the data collection began. To comply with ethical standards, the questionnaires were distributed as anonymous and the confidentiality of data obtained from the participants was ensured. After collecting the questionnaires, data analysis was performed using SPSS 23 and descriptive statistics (frequency, percentage, central tendency indexes, and dispersion).

\section{RESULTS}

The total number of samples studied in this research was reduced from 229 to 222 because of the incompleteness of some of the questionnaires and their removal from the study. The majority of samples were female $(84.7 \%)$ and married $(75.2 \%)$ with the mean age of $32.30 \pm 6.21$ and the average amount of work experience in intensive care units of $6.18 \pm 4.52 .92 .8 \%$ of the studied samples were nurses with a bachelor degree and $5.9 \%$ of them had higher degrees. 105 cases of nurses worked in ICU, 89 in the emergency unit, and 28 in the dialysis unit. 49 cases of the studied samples had signed a donor card (Table 1).

According to the results, the mean score of $89 \pm 12.17$ was obtained for altruism, $59.35 \pm 8.91$ for the empathy, and $48.25 \pm 8.50$ for the attitude. The mean score of attitude was higher in women than men $(\mathrm{p}=0.006)$ and in married people than the single ones $(p=0.02)$. The mean score of attitude was also higher in supervisors than nurses $(p=0.41)$. Additionally, it was higher in nurses working in ICU and dialysis units than those in the emergency units $(p=0.23)$. A significant relationship was not found between the attitude and education level $(\mathrm{p}=0.84)$ and employment status $(\mathrm{p}=0.81)$.

The results of the present study have shown that there was a positive correlation between altruism $(\mathrm{p}<0.001$ and $\mathrm{r}=0.24$ ) and its components, including anonymous prosocial behaviors $(\mathrm{p}<0.001$ and $\mathrm{r}=0.33)$, emotional
Table 1

Demographic characteristics of nurses in ICU, emergency and dialysis units of Educational and health Centers affiliated to Qazvin University of Medical Sciences

\begin{tabular}{|l|l|c|c|}
\hline & \multicolumn{1}{|c|}{ Variable } & Number & Percentage \\
\hline Unit & ICU & 105 & 47.3 \\
& Emergency & 89 & 40.2 \\
& Dialysis & 28 & 12.7 \\
\hline Gender & Male & 34 & 15.3 \\
& Female & 188 & 84.7 \\
\hline Marital status & Single & 54 & 24.4 \\
& Married & 167 & 75.6 \\
\hline Employment & Permanent & 92 & 41.6 \\
status & Temporary-to- & 21 & 9.5 \\
& permanent & & \\
& Passing & 53 & 24.0 \\
& a training course & & \\
& Contractual & 55 & 24.9 \\
\hline Organizational & Supervisor & 7 & 3.3 \\
position & Nurse & 203 & 96.7 \\
\hline Education level & Bachelor & 206 & 93.6 \\
& Master & 13 & 5.9 \\
& PhD & 1 & 0.5 \\
\hline
\end{tabular}

prosocial behaviors $(\mathrm{p}=0.03$ and $\mathrm{r}=0.14)$, dire prosocial behaviors $(p=0.03$ and $r=0.14)$, and compliant prosocial behaviors $(\mathrm{p}=0.001$ and $\mathrm{r}=0.21)$, and the attitudes of nurses toward organ donation. However, there was a negative correlation between public prosocial behaviors and the attitudes of nurses $(p=0.87$ and $r=$ -0.03 ). Concerning the variable of empathy, there was a positive correlation between the total score of empathy $(\mathrm{p}=0.04$ and $\mathrm{r}=0.13)$, perspective taking $(\mathrm{p}=0.02$ and $r=0.152)$, and fantasy $(p=0.03$ and $r=0.10)$ and the attitudes of nurses. There was no positive correlation between personal distress $(\mathrm{p}=0.13, \mathrm{r}=0.10)$ and empathic concern $(p=0.99$ and $r=0.00)($ Table 2$)$. The two variables of altruism and empathy have also had a positive correlation $(\mathrm{p}<0.001$ and $\mathrm{r}=0.420)$.

The results of multiple linear regression analysis, which was done to investigate the predictive role of research variables (quantitative and qualitative) in relation to the organ donation, have shown that gender, marital

Table 2

\section{Correlation between altruism and empathy with the attitudes of nurses in ICU, emergency and dialysis} units of Educational and Health Centers affiliated to Qazvin University of Medical Sciences

\begin{tabular}{|l|c|c|l|c|c|}
\hline \multirow{2}{*}{} & \multicolumn{2}{|c|}{ The total score of attitude } & \multicolumn{3}{|c|}{ The total score of attitude } \\
\cline { 2 - 6 } & $\begin{array}{c}\text { Correlation } \\
\text { coefficient }\end{array}$ & P-value & & $\begin{array}{c}\text { Correlation } \\
\text { coefficient }\end{array}$ & P-value \\
\hline Total score of altruism & 0.24 & $<0.001$ & Total score of empathy & 0.133 & 0.048 \\
\hline Anonymous prosocial behaviors & 0.338 & $<0.001$ & Personal distress & 0.102 & 0.131 \\
\hline Altruistic and public prosocial behaviors & -0.010 & 0.878 & Empathic concern & 0.000 & 0.997 \\
\hline Emotional prosocial behaviors & 0.144 & 0.031 & Perspective takes & 0.152 & 0.023 \\
\hline Dire prosocial behaviors & 0.143 & 0.033 & Fantasy & 0.140 & 0.037 \\
\hline Compliant prosocial behaviors & 0.219 & 0.001 & & & \\
\hline
\end{tabular}


Table 3

Predictors of the attitudes of nurses in ICU, emergency, and dialysis units toward organ donation in Educational and Health Centers affiliated to Qazvin University of Medical Sciences

\begin{tabular}{|l|c|c|c|c|c|c|}
\hline \multicolumn{1}{|c|}{ Variable } & B & Std. Error & Beta & P-value & \multicolumn{2}{c|}{ 95\% confidence interval } \\
\cline { 5 - 7 } & & & & & Minimum & Maximum \\
\hline Constant value & 19,922 & 5,339 & & 0.000 & $9 / 396$ & $30 / 448$ \\
\hline Gender & 4,172 & 1.540 & 0.175 & 0.007 & 1,136 & 7,208 \\
\hline Marital status & 0,999 & 1,323 & 0.51 & 0.451 & -1.609 & 3,608 \\
\hline Signing a donor card & 3,223 & 1.279 & 0.159 & 0.012 & 0,702 & 5.744 \\
\hline Anonymous prosocial behaviors & 0,582 & 0,148 & 0,349 & 0,000 & 0,290 & 0,874 \\
\hline Altruistic and public prosocial behaviors & $-0,64$ & 0,291 & $-0,18$ & 0,828 & $-0,637$ & 0,510 \\
\hline Emotional prosocial behaviors & $-0,431$ & 0,263 & $-0,148$ & 0,103 & $-0,951$ & 0,88 \\
\hline Dire prosocial behaviors & 0,321 & 0,288 & 0,083 & 0,266 & $-0,246$ & 0,889 \\
\hline Personal distress & $-0,020$ & 0,159 & $-0,009$ & 0,900 & $-0,333$ & 0,293 \\
\hline Empathic concern & 0,141 & 0,228 & 0,048 & 0,536 & $-0,308$ & 0,591 \\
\hline Perspective takes & 0,239 & 0,240 & 0,074 & 0,321 & $-0,234$ & 0,711 \\
\hline
\end{tabular}

status, signing a donor card, and altruism have been positive predictors of nurses' attitude toward organ donation and empathy has been the negative predictor (Table 3).

Linear regression was performed to assess the predictors of the attitudes toward organ donation. Variables that had $p>0.2$ in the single-variable model were entered into multiple linear regressions by "inter" method, that according to the results, the components of the anonymous prosocial behaviors $(\mathrm{p}<0.0001)$ in altruism and gender variables $(p=0.007)$ and having organ donation card ( $p=0.012)$ were significant predictors of nurses' attitude towards organ donation and in total, these variables predicted $20 \%$ change in attitude (Table 3 ).

\section{DISCUSSION}

The results obtained from the present study that has aimed to investigate the relationship between empathy and altruism with the attitude of nurses toward organ donation confirm the effect of altruism on the attitude of nurses toward organ donation. There was a direct and significant relationship between the total score of altruism and such components as anonymous prosocial behaviors, emotional prosocial behaviors, dire prosocial behaviors, and compliant prosocial behaviors with the attitudes of nurses toward organ donation. This is in agreement with the results obtained from the study by Khani et al. (2016), which showed a significant direct relationship between altruism and the attitude toward organ donation as well as a significant indirect relationship between the altruism caused by practicing religious beliefs and the attitude toward the organ donation [14]. Hill et al. (2016) demonstrated that there was a moderate positive correlation between the altruism and the attitude toward the organ donation and among the altruism and big five personality dimensions, only altruism was an important predictor of decision making on organ donation [16]. In the study by Khani et al. (2014) that investigated the role of social capitals and altruism in the prediction of medical doctors' attitudes toward organ donation, a posi- tive and significant correlation was recognized between the attitude toward the organ donation and the altruism [32]. In the study conducted by Newton et al. (2011), the altruistic motivation to help others was introduced as the most commonly identified motivator for becoming an organ donor [15]. It can be said that the feeling of altruism has a significant effect on the attitude of nurses toward organ donation and improves the performance of nurses in identifying brain death patients, caring for them, and increasing the consent of their families for the organ donation.

The results have also shown that there was a direct and significant correlation between the total score of empathy, perspective taking, and fantasy with the attitude of nurses. However, there was no correlation between distress and empathic concern. In study of Cohen et al. (2012), empathic concern and self-interest (personal distress) were considered as a positive predictor of tendency to organ donation, while paying attention to the interests of others (empathic attention) was not the positive predictor of tendency to organ donation. In the present study, there was a significant relationship between imaginary empathy and perspective taking with attitude toward organ donation, but none of the subscales of empathy was not a positive predictors of nurses' attitude toward donation [17]. The research conducted by Wilczek et al. (2014) demonstrated that there was no significant correlation between empathy and the willingness to donate organs of brain death patients. It is in contrast to the results of the present study. Their study showed that the highest percentage of empathy was associated with the female participants [19], which is in agreement with this study.

The results of the study by Milaniak et al. (2018) showed a significant correlation between altruism and empathy with the causes of posthumous organ donation. In their study, the highest percentage of willing to sign a donor card was associated with the group who had a moderate level of altruism, and the highest percentage of 
those who had signed previously a donor card was seen in the group with a high level of altruism [7]. These are consistent with the findings of the present study. In terms of empathy, only perspective taking was considered as a significant predictor and there was a poor relationship between the perspective taking and the dependent variable. There was a significant difference between the level of personal distress and disagreement with the organ donation. There was a positive and significant correlation between the fantasy and the agreement with the organ donation after the death of relatives, which was in agreement with the present study, but in the present study, none of the empathy subscales were positive predicator of the attitude toward organ donation [7]. There was no correlation between altruism and empathy that this finding was not in agreement with our study [7]. Empathy affected the agreement with donating organs of relatives after brain death and those with a higher level of empathy tended to develop a more positive attitude toward organ donation. According to the findings of the study it can be concluded that nurses with a high level of empathy can improve the status of organ donation in the society by developing more positive attitudes toward organ donation in relatives of brain death patients. In addition, the present study has shown that the score of attitude has been higher in those who have signed a donor card and signing a donor card has a positive and significant correlation with a positive attitude toward organ donation. In the study by Purbahram et al. (2017), the score of attitude in nurses who signed a donor card was higher than those who didn't sign a donor card. However, this difference was not significant [31]. The study conducted by Rodrigue (2004) also demonstrated that those who signed a donor card had more positive attitudes toward organ donation than those who didn't sign a donor card [34]. In the present study the gender, marital status and the component of anonymous prosocial behaviors have been a positive predictor of attitude toward organ donation while the effect of age, marital status, other component of altruism and also empathy and its components has not been significant. It is not in agreement with the findings of the study by Hill (2016), in which the age was the positive predictor of the attitude toward the organ donation and the gender was the negative predictor of it [16], as well as the results of study by Rodrigue (2004), in which the gender and marital status had no relationship with the attitudes and beliefs toward the organ donation [34].

Considering the necessity of research in the field of organ donation and the increasing need of the society for it, it is suggested that different methods to be used to increase the feelings of altruism and empathy to strengthen the positive attitude toward the organ donation among nurses in intensive care units.

\section{CONCLUSION}

The results of our research show that empathy and altruism can lead to positive attitudes of nurses toward the organ donation and improve their performance in the organ donation process and ultimately, promote the status of organ donation in the society. More research is needed to understand how empathy and altruism affect the organ donation process. The results showed that altruism and having organ donation card were the most important factors in the tendency of nurses to organ donation. Therefore, the implementation of educational programs regarding changing nurse's attitude in order to increase the sense of altruism and empathy about organ donation is necessary. By strengthening the sense of altruism and empathy in the family of brain death patients, they can be helped to decide on donate their patient's organ with more certainty.

\section{LIMITATIONS}

The present study has been of the kind of correlational research and as a limitation, it cannot be said that the predictor variables have been the main cause of the independent variable. It is suggested that the effects of other psychological and social characteristics on the attitudes of nurses toward the organ donation to be investigated in the next research.

The present research is correlational and as a limitation, it can not be said that the predictor variables are the main cause of the independent variable. Secondly, a questionnaire was used to collect the data. Therefore, considering that the questionnaires had an aspect of self-evaluation, there might be a bias (orientation) in the responses. Therefore, it is suggested that interview and observation be used in subsequent studies. It is also suggested that in the subsequent studies, other tools for measuring altruism and empathy and the effects of other psychological and social characteristics on the nurses' attitude towards organ donation should be investigated.

\section{The authors declare no conflict of interest. Авторы заявляют об отсутствии конфликта интересов.}

\section{REFERENCES / СПИСОК АИТЕРATУРЫ}

1. Grinyó $J M$. Why is organ transplantation clinically important? Cold Spring Harbor perspectives in medicine. 2013; 3 (6): a014985.

2. Vlaisavljevic Z, Živanović D. A nurse is an important factor in increasing organ donation. 2018. 91-94 p.

3. Sánchez-Vallejo A, Gómez-Salgado J, Fernández-Martínez MN, Fernández-García D. Examination of the Brain-Dead Organ Donor Management Process at a Spanish Hospital. International journal of environmental research and public health. 2018; 15 (10): 2173.

4. Kiani M, Abbasi M, Ahmadi M, Salehi B. Organ Transplantation in Iran; Current State and Challenges with a View on Ethical Consideration. J Clin Med. 2018; 7 (3). 
5. Baghi V, Dalvand S, Farajzadeh M, Nazari M, GHanei $G R$. Evaluation of knowledge and attitude towards organ donation among the residents of Sanandag city, Iran. 2017; 4 (1): 1-8.

6. Mohebi S, Mohammadi-zavareh M, Zamani F, Gharlipor Z, Heidary H. Factors Affecting Qom Medical School Students' Intention regarding Organ Donation: a Study based on Behavioral Intention Model. Journal of Health Literacy. Autumn 2016; 1 (3): 147-154.

7. Milaniak I, Wilczek-Rużyczka E, Przybyłowski P. Role of Empathy and Altruism in Organ Donation Decisionmaking Among Nursing and Paramedic Students. Transplantation proceedings. 2018; 50 (7): 1928-1932.

8. Miller $C$, Breakwell $R$. What factors influence a family's decision to agree to organ donation? A critical literature review. London journal of primary care. 2018; 10 (4): 103-107.

9. Moorlock G, Ives J, Draper H. Altruism in organ donation: an unnecessary requirement? Journal of medical ethics. 2014; 40 (2): 134-138.

10. Carlo $G$, Randall BA. The development of a measure of prosocial behaviors for late adolescents. Journal of youth and adolescence. 2002; 31 (1): 31-44.

11. Feigin $S$, Owens $G$, Goodyear-Smith $F$. Theories of human altruism: A systematic review. Journal of Psychiatry and Brain Functions. 2018; 1 (1): 5.

12. Eisenberg-Berg N, Cameron E, Tryon K, Dodez R. Socialization of prosocial behavior in the preschool classroom. Developmental Psychology. 1981; 17 (6): 773.

13. Eisenberg N, Fabes R. Prosocial development (In W. Damon \& N. Eisenberg (Eds.). Handbook of child psychology: Social, emotional, and personality development. Berlin: Springer; 1998; 3: 701-778.

14. Khani L, Hashemianfar SA, Ghaffari M, Smaili R. The role of moral beliefs and altruism in explaining attitudes toward organ donation with the mediation of act to religious belief. Med Ethics. J 2017; 11 (39): 45-53.

15. Newton JD. How does the general public view posthumous organ donation? A meta-synthesis of the qualitative literature. BMC Public Health. 2011; 11 (1): 791.

16. Hill EM. Posthumous organ donation attitudes, intentions to donate, and organ donor status: Examining the role of the big five personality dimensions and altruism. Personality and Individual Differences. 2016; 88: 182-186.

17. Cohen EL, Hoffner C. Gifts of giving: the role of empathy and perceived benefits to others and self in young adults' decisions to become organ donors. Journal of Health Psychology. 2013; 18 (1): 128-138.

18. Davis M. Empathy: A Social Psychological Approach, 1994. Brown and Benchmark Publishers, Madison, WI.

19. Wilczek-Ruzyczka E, Milaniak I, Przybytowski P, Wierzbicki K, Sadowski J, editors. Influence of empathy, beliefs, attitudes, and demographic variables on willingness to donate organs. Transplantation proceedings; 2014: Elsevier.

20. Resnick S, Seamon MJ, Holena D, Pascual J, Reilly PM, Martin ND. Early declaration of death by neurologic criteria results in greater organ donor potential. Journal of Surgical Research. 2017; 29: 218-234.

21. Bahrami A, Khaleghi E, Vakilzadeh AK, Afzalaghaee M. Process and barriers to organ donation and causes of brain death in northeast of Iran. Electronic physician. 2017; 9 (2): 3797-3802.

22. O'Leary GM. Deceased donor organ donation: The critical care nurse's role. Nursing. 2019 Critical Care. 2018; 13 (4): 27-32.

23. Mills L, Koulouglioti $C$. How can nurses support relatives of a dying patient with the organ donation option? Nursing in critical care. 2016; 21 (4): 214-224.

24. Manzari Z, Masoumian Hoseini ST, Karimi Moonaghi H, Behnam Vashani H. Effect of Education Based on Nursing Model of Dynamism and Continuous Improvement in Seeking Assurance and Getting Approve on Nurses' Knowledge, Attitude and Practice about Their Role in Organ Donation Process. J Mazand Univ Med Sci. 2014; 24 (119): 141-153.

25. Nacar M, Cetinkaya F, Baykan Z, Elmali F. Knowledge Attitudes and Behaviors About Organ Donation Among First- and Sixth-class Medical Students: A Study From Turkey. Transplantation proceedings. 2015; 47 (6): 1553-1559.

26. Carlo G, Hausmann A, Christiansen S, Randall BA. Sociocognitive and behavioral correlates of a measure of prosocial tendencies for adolescents. The journal of early adolescence. 2003; 23 (1): 107-134.

27. Mohammdbagher Kajbaf, Elnaz Sajjadian, Abolghasem Nouri. A Study of Factor Structur, Validity and Reliabileaty of Pro-social Tendencies Measure Revised Questionnaire Among University Students. Journal of applied sociology. 2010; 21 (2): 101-118.

28. Davis $M$. Measuring individual differences in empathy: Evidence for a multidimensional approach. 1983: 113126.

29. Khodabakhsh MR. Relationship between Attachment Style and Empathy in Nursing Students. IJN. 2012; 25 (77): 40-49.

30. Alah Gholilo K, Abolghasemi A, Zahed A. The Relationship of Mindfulness Skills and Metacognitive Beliefs with Interpersonal Reactivity of Substance Abusers. Journal of clinical psychology. 2014; 6 (3): 33-41.

31. Purbahram R, Ashktorab T, Barazabadi Farahani Z, Nasiri M. Knowledge and Attitude of the Intensive Care Unit Nurses in Mazandaran Province towards Organ Donation. Iran Journal of Nursing. 2017; 30 (107): 1-9.

32. Khani (MA) L, Ghaffari (MA) M, Hashemian Far $(P h D) S$. The Role of Social Capital and Altruism in Prediction of Medical Doctors' Attitudes to Organ Donation. JBUMS. 2014; 16 (8): 19-25.

33. AlHejaili W, Almalik F, Albrahim L, Alkhaldi F, AlHejaili A, AlSayyari A. Scores of awareness and altruism in organ transplantation among Saudi health colleges students-impact of gender, year of study, and field of specialization. Saudi J Kidney Dis Transpl. 2018; 29 (5): 1028-1034.

34. Rodrigue James R, Cornell Danielle L, Jackson Shannon I, Kanasky William, Marhefka Stephanie, Reed Alan I. Are organ donation attitudes and beliefs, empathy, and life orientation related to donor registration status? Progress in Transplantation. 2004; 14 (1): 56-60.

The article was submitted to the journal on 4.06.2019 Статья поступила в редакциию 4.06.2019 2. 